\section{Chemical Constituents from the Fungus Amauroderma amoiensis and Their In Vitro Acetylcholinesterase Inhibitory Activities}

\author{
Shuang Shuang Zhang ${ }^{1,2}$, Qing Yun Ma ${ }^{2}$, Xi Sheng Zou ${ }^{3}$, \\ Hao Fu Dai ${ }^{2}$, Sheng Zhuo Huang ${ }^{2}$, Ying Luo ${ }^{2}$, Zhi Fang Yu ${ }^{1}$, \\ Huai Rong Luo ${ }^{3}$, You Xing Zhao ${ }^{2}$ \\ ${ }^{1}$ Food Science and Technology College, Nanjing Agricultural \\ University, Nanjing, China \\ 2 Institute of Tropical Bioscience and Biotechnology, Chinese \\ Academy of Tropical Agricultural Sciences, Haikou, China \\ ${ }^{3}$ State Key Laboratory of Phytochemistry and Plant Resources in \\ West China, Kunming Institute of Botany, Chinese Academy of \\ Sciences, Kunming, China
}

\section{Abstract \\ $\nabla$}

One new compound named amauroamoienin (1), together with thirteen known compounds (2-14), was isolated from the EtOAc extract of Amauroderma amoiensis. The structures of these compounds were elucidated by the analysis of $1 \mathrm{D}$ and 2D spectroscopic data and the MS technique. The bioassays of inhibitory activities of these isolates against acetylcholinesterase were evaluated, and compounds 1, 3, and 5 exhibited acetylcholinesterase inhibitory activities.

\section{Key words}

Amauroderma amoiensis · Ganodermataceae · amauroamoie$\mathrm{nin} \cdot$ acetylcholinesterase inhibitory activity

Supporting information available online at http://www.thieme-connect.de/ejournals/toc/plantamedica

The family Ganodermataceae comprising more than 200 fungal species is mainly distributed in the tropical and subtropical areas of Asia, Australia, Africa, and America [1]. More than 100 species of this family grow in China, of which 78 wild species were found in Hainan Province [2]. Ganoderma and Amauroderma are two genera of the Ganodermataceae family. A great deal of work has been carried out on the genus Ganoderma [3]. Two of its species, recorded in the Chinese Pharmacopoeia, G. lucidum and G. sinense, have been used for the treatment of migraine, hypertension, arthritis, bronchitis, asthma, gastritis, diabetes, nephritis, and hepatitis problems for centuries [4,5]. Recent research on the chemical constituents of Ganoderma species showed the presence of natural products including triterpenes, steroid, alkaloids, flavonoids, polysaccharides, and fatty acids [6-8]. Previous screening of acetylcholinesterase (AChE) inhibitors from fungal extracts showed that many fungi, including the genera of the Ganodermataceae family, exhibited inhibitory activities against AChE [9]. At present, chemical constituents from many Amauroderma species, including Amauroderma amoiensis (Zhao) found in Fujian and Hainan Province of China [10], and their biological activities are still not reported.

In order to study the bioactive constituents of A. amoiensis, a chemical investigation was carried out and led to the isolation of one new compound, named amauroamoienin (1), along with thirteen known compounds (2-14) ( $\bullet$ Fig. 1), 4-hydroxy-17methylincisterol (2) [11], (17R)-17-methylincisterol (3) [12], 1,5dihydroxy-6',6'-dimethylpyrano[2',3':3,2] xanthone (4) [13], jacareubin (5) [13], ergosterol peroxide (6) [14], ergosta-7,22-dien$3 \beta$-ol (7) $[15,16],(22 E, 24 \mathrm{R})$-ergosta-8,22E-diene-3 $\beta, 5 \alpha, 6 \beta, 7 \alpha$ tetraol (8) $[17,18], \quad 22 \mathrm{E}-7 \alpha$-methoxy- $5 \alpha, 6 \alpha$-epoxyergosta-8 (14),22-dien-3 $\beta$-ol (9) [19], 3 $\beta, 5 \alpha, 9 \alpha$-trihydroxyergosta-7,22-dien-6-one (10) [20,21], 1H-indole-3-carboxylic acid (11) [22], $p$ hydroxybenzoic acid (12) [23], methyl 3,4-dihydroxybenzoate (13) [24], and 7,8-dimethylalloxazine (14) [25]. Herein, we describe the isolation and structural elucidation of the new compound (1), as well as the AChE inhibitory activities of all isolates. Compound 1 was obtained as a yellow amorphous powder, and its molecular formula was assigned to be $\mathrm{C}_{46} \mathrm{H}_{54} \mathrm{O}_{7}$ from its HREIMS ( $m / z 718.3871[\mathrm{M}]^{+}$, calcd. for $\left.\mathrm{C}_{46} \mathrm{H}_{54} \mathrm{O}_{7}, 718.3870\right)$ and NMR data ( Table 1), indicating twenty degrees of unsaturation. The IR spectrum displayed the presence of hydroxyl $\left(3353 \mathrm{~cm}^{-1}\right)$, carbonyl $\left(1726 \mathrm{~cm}^{-1}\right)$, and double bond $\left(1621 \mathrm{~cm}^{-1}\right)$ absorptions. Analysis of ${ }^{13} \mathrm{C}$ NMR and DEPT spectra ( Table 1 ) showed 46 carbon resonances including eight for methyls, six for methylenes, sixteen for methines (two oxygenated), and sixteen for quaternary carbons (including one carbonyl). The ${ }^{13} \mathrm{C}$ NMR spectra showed resonances characteristic of the structure consisting of an ergostane moiety and a xanthone moiety. Comparison of 18 carbon signals of compound 1 with those of jacareubin (5) [14] hinted that 1 had a xanthone moiety with the same structure of that of $\mathbf{5}$, which was also confirmed by olefinic and aromatic protons signals [ $\delta_{\mathrm{H}} 6.71(1 \mathrm{H}, \mathrm{d}, J=10.1 \mathrm{~Hz}), 5.57(1 \mathrm{H}, \mathrm{d}, J=10.1 \mathrm{~Hz})$, $\delta_{\mathrm{H}} 6.39(1 \mathrm{H}, \mathrm{s}), 6.88(1 \mathrm{H}, \mathrm{d}, J=8.9 \mathrm{~Hz})$, and $7.67(1 \mathrm{H}, \mathrm{d}$, $J=8.9 \mathrm{~Hz}$ )], and two resonance signals $\left[\delta_{\mathrm{H}} 1.45\right.$ and 1.46 (each $1 \mathrm{H}, \mathrm{s})]$ for methyl groups similar to those of jacareubin. The ${ }^{1} \mathrm{H}-{ }^{1} \mathrm{H}$ COSY correlations of $\mathrm{H}-7^{\prime} / \mathrm{H}-8^{\prime}$ and $\mathrm{H}-13^{\prime} / \mathrm{H}-14^{\prime}$ and $\mathrm{HMBC}$ correlations ( Fig. 2) further deduced the presence of a jacareubin moiety in $\mathbf{1}$. The remaining 28 carbon signals in compound 1 were reasonably characteristic of an ergostane steroid skeleton which was the basic natural product isolated from this genus. The steroid moiety possessed six olefinic carbons $\left[\delta_{\mathrm{C}} 115.9(\mathrm{~d})\right.$, 124.0 (d), 132.5 (d), 135.6 (d), 140.0 (s), 141.0 (s)], two oxygenated methines $\left[\delta_{C} 66.8,73.6\right]$, and one oxygenated quaternary carbon $\left[\delta_{C} 77.3\right]$, among which an epoxy group was formed based on analysis of its molecular formula. Comparison of these ${ }^{13} \mathrm{C}$ NMR data with those of (22E,24R)-ergosta-7,9(11),22-triene$3 \beta, 5 \alpha, 6 \beta$-triol [26] suggested that they might have identical skeletons except for the difference of three oxygenated carbons. The key HMBC correlations from H-6 $\left(\delta_{\mathrm{H}} 4.73, \mathrm{~s}\right)$ to $\mathrm{C}-6^{\prime}, \mathrm{C}-7$, and C-8 indicated that the steroid and xanthone moieties were connected via an oxygen at C-6 and C-6', which also confirmed the epoxy group formed at two other oxygenated carbons. The HMBC correlation from $\mathrm{H}-19\left(\delta_{\mathrm{H}} 1.24, \mathrm{~s}\right)$ to $\mathrm{C}-5\left(\delta_{\mathrm{C}} 77.3\right)$ showed that the epoxy group was at $\mathrm{C}-4$ and $\mathrm{C}-5$. The stereochemistry of the chiral centers (C-10, C-13, C-14, C-17) and the side chain at C-20 and $\mathrm{C}-24$ of the steroid moiety in $\mathbf{1}$ were proposed to be the same as those of (22E,24R)-ergosta-7,9(11),22-triene-3 $\beta, 5 \alpha, 6 \beta$-triol by comparison of the their ${ }^{13} \mathrm{C}$ NMR data, with the possible $\beta$-orientations of $\mathrm{CH}_{3}-18$ and $\mathrm{CH}_{3}-19$ and $\alpha$-orientations of $\mathrm{H}-14$ and $\mathrm{H}-$ 17 [26]. The $\beta$-orientation of H- 6 was determined by the key NOE of $\mathrm{H}-6 / \mathrm{H}-19$ ( Fig. 2). The weak correlations of $\mathrm{H}-6$ and $\mathrm{H}-4$ $\left(\delta_{\mathrm{H}} 3.93, \mathrm{~m}\right)$ with the same proton $\mathrm{H}-2 \mathrm{~b}\left(\delta_{\mathrm{H}} 1.61, \mathrm{~m}\right)$ proposed the $\beta$-orientation of $\mathrm{H}-4$, which accordingly hinted the $\alpha$-orientation of the epoxy group in 1 . NOE of $\mathrm{H}-18 / \mathrm{H}-20$ further confirmed 


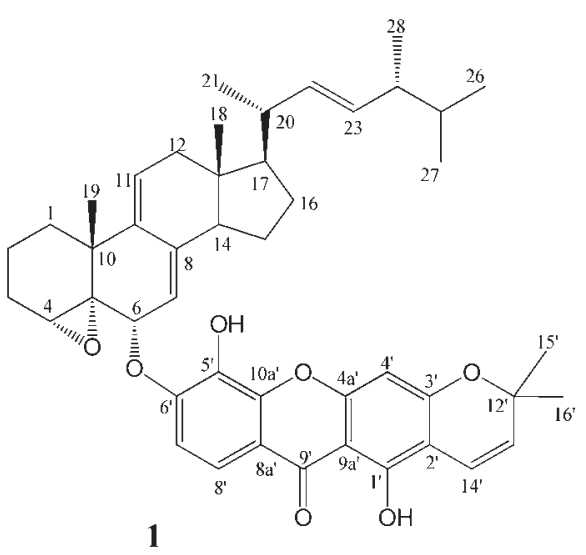<smiles>[R][C@]12CC[C@@]3(C)[C@@H](CC[C@@H]3[C@H](C)/C=C/[C@H](C)C(C)C)C1=CC(=O)O2</smiles>

$2 \mathrm{R}=\mathrm{OH}$ $3 \mathrm{R}=\mathrm{OMe}$<smiles>[R]c1ccc2c(=O)c3c(O)c4c(cc3oc2c1O)OC(C)(C)C=C4</smiles>

$4 \mathrm{R}=\mathrm{H}$

$5 \mathrm{R}=\mathrm{OH}$

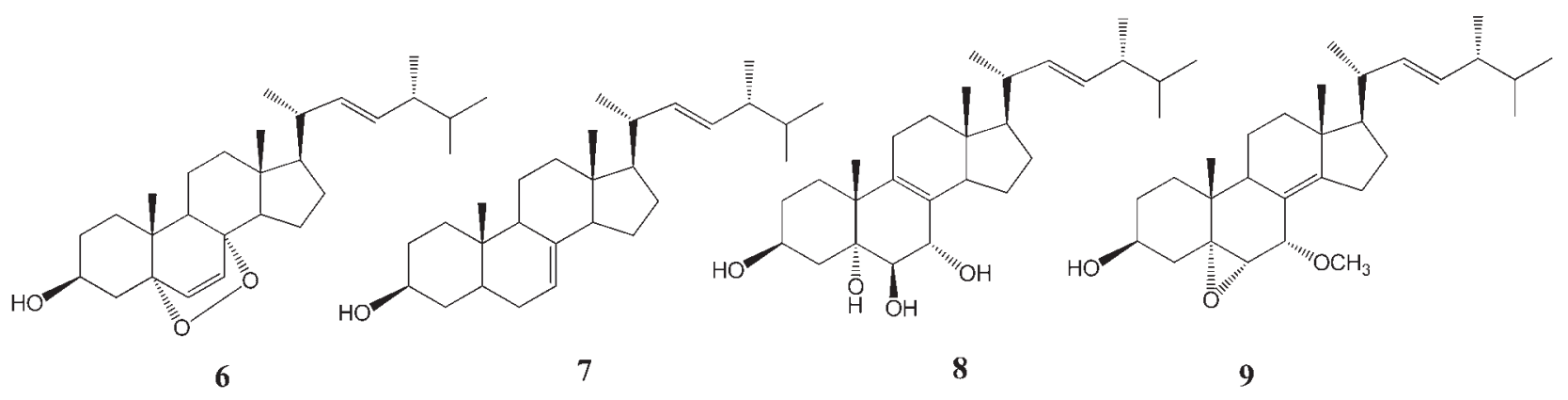<smiles>CC(C)[C@H](C)/C=C/[C@H](C)[C@H]1CCC2C3=CC(=O)[C@]4(O)C[C@@H](O)CC[C@]4(C)[C@@]3(C)CC[C@]21C</smiles>

10<smiles>O=C(O)c1c[nH]c2ccccc12</smiles>

11<smiles>[R]OC(=O)c1ccc(O)c([R])c1</smiles>

$12 \mathrm{R}_{1}=\mathrm{H} \quad \mathrm{R}_{2}=\mathrm{H}$

$13 \mathrm{R}_{1}=\mathrm{OH} \mathrm{R}=\mathrm{Me}$<smiles>Cc1cc2nc3[nH]c(=O)[nH]c(=O)c3nc2cc1C</smiles>

14

Fig. 1 Structures of compounds 1-14.

the $\beta$-orientation of $\mathrm{CH}_{3}-18$ and the $\alpha$-orientation of $\mathrm{H}-17$. Thus, the structure of compound 1 was assigned as shown in 0 Fig. $\mathbf{1}$, and this compound was named amauroamoienin.

The AChE inhibitory activities for compounds 1-11 were tested. The purities of all compounds were more than $98 \%$ by HPLC analyses. Compound 3 showed a certain inhibitory activity (inhibition percentage was $46.33 \%$ ) at the concentration of $100 \mu \mathrm{M}$, and compounds $\mathbf{1}$ and $\mathbf{5}$ showed weak inhibitory activity (inhibition percentages were $14.63 \%$ and $25.49 \%$, respectively) (Table 2 ). Meanwhile, the other compounds were inactive with inhibition ratios less than $10 \%$.

\section{Materials and Methods}

$\nabla$

The fruiting bodies of $A$. amoiensis were collected in Lingshui County, Hainan Province, People's Republic of China in June 2011 and identified by Prof. Xing-Liang Wu of the Hainan University. A voucher specimen (No. 2011JZ01) was deposited at the Institute of Tropical Bioscience and Biotechnology, Chinese Academy of Tropical Agricultural Sciences.
Extraction and isolation: The dried and powdered fruiting bodies of A. amoiensis ( $6.0 \mathrm{~kg}$ ) were extracted at room temperature with $95 \%$ EtOH ( $3 \times 20$ L, 7 d each). The extract was concentrated and suspended in water followed by successive partition with EtOAc and $n$ - $\mathrm{BuOH}$, respectively. The EtOAc extract (70.8 g) was separated by silica gel column chromatography (CC) $(10 \times 40 \mathrm{~cm}$, $560.0 \mathrm{~g})$ under vacuum using a gradient eluent mixture of petroleum ether/EtOAc $(20: 1-3: 1,3 \mathrm{~L}$ each) to afford nine fractions (Fr 1-Fr 9). Fraction 4 (3.2 g) was subjected to silica gel CC $(4 \times 30 \mathrm{~cm}, 30.0 \mathrm{~g})$ under vacuum eluted with petroleum ether/ EtOAc (10:1-3:1, 1 L each) to give 6 subfractions $4 a-4$ f. Subfraction $4 \mathrm{~d}$ (350.0 mg) was subjected to CC with Sephadex LH-20 $\left(2 \times 100 \mathrm{~cm}, \mathrm{CHCl}_{3} / \mathrm{MeOH} 1: 1,1 \mathrm{~L}\right)$ to yield compound $4(5.0 \mathrm{mg})$. Fraction 5 ( $7.3 \mathrm{~g})$ was subjected to silica gel CC $(5.5 \times 30 \mathrm{~cm}$, $70.0 \mathrm{~g})$ eluted with petroleum ether/EtOAc (4:1-1:1, $3 \mathrm{~L}$ each) to give 5 subfractions $5 \mathrm{a}-5 \mathrm{e}$. Subfraction $5 \mathrm{a}(447.0 \mathrm{mg})$ was repeatedly purified by silica gel CC $(2 \times 45 \mathrm{~cm}, 24.0 \mathrm{~g})$ eluted with petroleum ether/EtOAc $(7: 1,3 \mathrm{~L})$ and Sephadex LH-20 $\left(2 \times 100 \mathrm{~cm}, \mathrm{CHCl}_{3} / \mathrm{MeOH} 1: 1,500 \mathrm{~mL}\right)$ to yield compound 1 (11.9 mg). Subfraction $5 \mathrm{~b}(2.4 \mathrm{~g})$ was chromatographed on silica gel CC $(3 \times 30 \mathrm{~cm}, 20.0 \mathrm{~g})$ eluted with petroleum ether $/$ EtOAC 
Table $1{ }^{1} \mathrm{H}$ NMR ( $500 \mathrm{MHz}$ ) and ${ }^{13} \mathrm{C}$ NMR $\left(125 \mathrm{MHz}\right.$ ) data of compounds 1 and 5 in $\mathrm{CDCl}_{3}$ ( $\delta_{\mathrm{H}}$ in ppm, $J$ in $\mathrm{Hz}$ ).

\begin{tabular}{|c|c|c|c|c|c|c|c|}
\hline & 1 & & & & & 5 & \\
\hline No & $\delta_{\mathrm{H}}, J(\mathrm{~Hz})$ & $\delta_{C}$ & No & $\delta_{\mathrm{H}}$ & $\delta_{C}$ & $\delta_{\mathrm{H}}, J(\mathrm{~Hz})$ & $\delta_{\mathrm{C}}$ \\
\hline 1 & $1.69(\mathrm{~m}), 1.90(\mathrm{~m})$ & 30.0 & $1^{\prime}$ & & 160.5 & & 159.5 \\
\hline 2 & $1.28(\mathrm{~m}), 1.61(\mathrm{~m})$ & 23.2 & $2^{\prime}$ & & 104.8 & & 103.7 \\
\hline 3 & $1.59(\mathrm{~m}), 2.16(\mathrm{~m})$ & 35.4 & $3^{\prime}$ & & 157.9 & & 156.9 \\
\hline 4 & $3.93(\mathrm{~m})$ & 66.8 & $4^{\prime}$ & $6.39(s)$ & 95.6 & $6.37(\mathrm{~s})$ & 94.6 \\
\hline 5 & & 77.3 & $4 a^{\prime}$ & & 157.2 & & 156.4 \\
\hline 6 & $4.73(\mathrm{~s})$ & 73.6 & $5^{\prime}$ & & 130.2 & & 132.5 \\
\hline 7 & $5.05(s)$ & 115.9 & $6^{\prime}$ & & 146.7 & & 152.1 \\
\hline 8 & & 141.0 & $7^{\prime}$ & $6.88(\mathrm{~d}, 8.9)$ & 114.1 & $6.93(\mathrm{~d}, 8.7)$ & 113.2 \\
\hline 9 & & 140.0 & $8^{\prime}$ & $7.67(\mathrm{~d}, 8.9)$ & 117.2 & $7.50(\mathrm{~d}, 8.7)$ & 115.9 \\
\hline 10 & & 40.6 & $8 a^{\prime}$ & & 115.5 & & 112.9 \\
\hline 11 & $5.69(d, 6.4)$ & 124.0 & $9^{\prime}$ & & 180.7 & & 179.9 \\
\hline 12 & $2.22(\mathrm{~m}), 2.35(\mathrm{~m})$ & 42.3 & $9 a^{\prime}$ & & 103.6 & & 102.2 \\
\hline 13 & & 42.8 & 10a’ & & 147.1 & & 146.0 \\
\hline 14 & $2.19(\mathrm{~m})$ & 51.1 & $12^{\prime}$ & & 78.3 & & 78.1 \\
\hline 15 & $1.71(\mathrm{~m}), 2.24(\mathrm{~m})$ & 28.9 & $13^{\prime}$ & $5.57(d, 10.1)$ & 127.6 & $5.71(\mathrm{~d}, 10.1)$ & 128.1 \\
\hline 16 & $1.69(\mathrm{~m}), 2.05(\mathrm{~m})$ & 31.0 & $14^{\prime}$ & $6.71(d, 10.1)$ & 115.8 & $6.57(d, 10.1)$ & 114.5 \\
\hline 17 & $1.27(\mathrm{~m})$ & 56.2 & $15^{\prime}$ & $1.45(\mathrm{~s})$ & 28.7 & $1.41(\mathrm{~s})$ & 27.9 \\
\hline 18 & $0.56(s)$ & 12.0 & $16^{\prime}$ & $1.46(\mathrm{~s})$ & 28.6 & $1.41(\mathrm{~s})$ & 27.9 \\
\hline 19 & $1.24(\mathrm{~s})$ & 24.5 & & & & & \\
\hline 20 & $2.01(\mathrm{~m})$ & 40.6 & & & & & \\
\hline 21 & $1.00(\mathrm{~d}, 6.6)$ & 21.0 & & & & & \\
\hline 22 & $5.11(\mathrm{dd}, 8.3,15.3)$ & 135.6 & & & & & \\
\hline 23 & $5.20(\mathrm{dd}, 7.7,15.3)$ & 132.5 & & & & & \\
\hline 24 & $1.92(\mathrm{~m})$ & 43.1 & & & & & \\
\hline 25 & $2.06(\mathrm{~m})$ & 33.3 & & & & & \\
\hline 26 & $0.79(\mathrm{~d}, 6.8)$ & 19.9 & & & & & \\
\hline 27 & $0.81(\mathrm{~d}, 6.8)$ & 20.2 & & & & & \\
\hline 28 & $0.89(\mathrm{~d}, 6.8)$ & 17.9 & & & & & \\
\hline
\end{tabular}

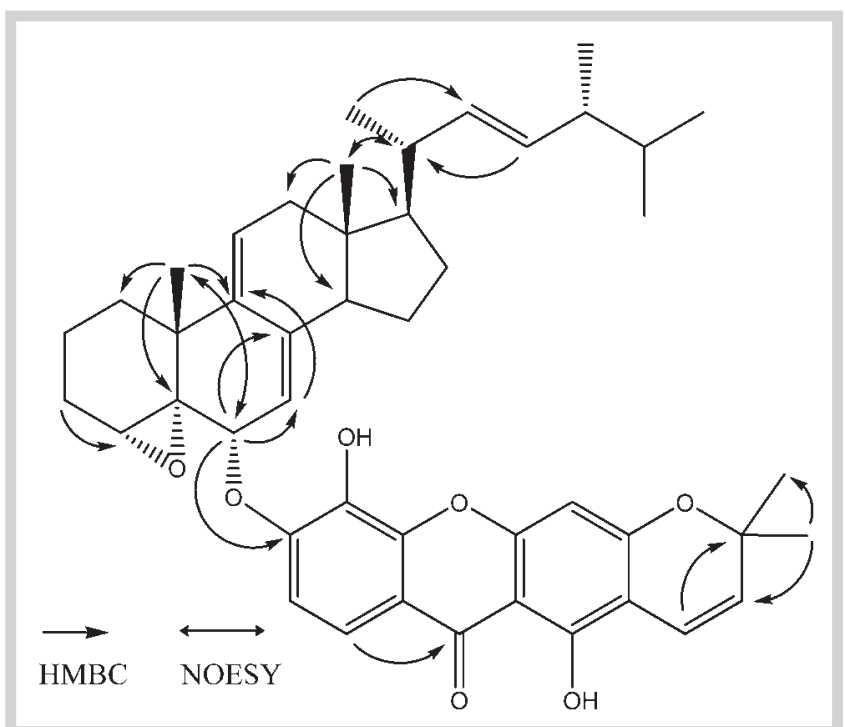

Fig. 2 Key HMBC and NOESY correlations of compound $\mathbf{1}$.

$(4: 1,4 \mathrm{~L})$ to yield compound 6 (19.6 mg). Subfraction $5 \mathrm{c}$ $(169.2 \mathrm{mg})$ was separated by silica gel CC $(1.2 \times 34 \mathrm{~cm}, 9.0 \mathrm{~g})$ eluted with petroleum ether/EtOAc $(5: 1,3 \mathrm{~L})$ to yield compound 7 (3.8 mg). Fraction 6 ( $3.7 \mathrm{~g})$ was separated by silica gel CC $(4 \times 30 \mathrm{~cm}, 32 \mathrm{~g})$ using as eluent petroleum ether/EtOAc $(4: 1-$ $1: 1,2 \mathrm{~L}$ each) to afford subfractions 6a-6e. Subfraction 6e $(671.7 \mathrm{mg})$ was gel-filtrated on Sephadex LH-20 $(2 \times 100 \mathrm{~cm}$,
$\mathrm{CHCl}_{3} / \mathrm{MeOH} 1: 1,1.2 \mathrm{~L}$ ) to yield compound 2 (10.9 mg). Subfraction $6 \mathrm{~d}(332.0 \mathrm{mg})$ was gel-filtrated on Sephadex LH-20 $\left(2 \times 100 \mathrm{~cm}, \mathrm{CHCl}_{3} / \mathrm{MeOH} 1: 1,500 \mathrm{~mL}\right)$ and then separated by silica gel column $(1.2 \times 34 \mathrm{~cm}, 8.0 \mathrm{~g})$ using as eluent petroleum ether/EtOAc $(15: 1,1 \mathrm{~L})$ to yield compound $3(8.9 \mathrm{mg})$. Fraction 7 $(4.7 \mathrm{~g})$ was separated by vacuum liquid column $(4 \times 30 \mathrm{~cm}, 50.0 \mathrm{~g})$ using as eluent petroleum ether/EtOAc $(3: 2-1: 2,2 \mathrm{~L})$ to afford subfractions $7 \mathrm{a}-7 \mathrm{~g}$. Subfraction $7 \mathrm{c}(520 \mathrm{mg})$ was subjected to Sephadex $\mathrm{LH}-20\left(2 \times 100 \mathrm{~cm}, \mathrm{CHCl}_{3} / \mathrm{MeOH} 1: 1,800 \mathrm{~mL}\right)$ to yield compound 11 (5.2 mg). Subfractions 7a and 7b were separated by silica gel column to yield compounds $12(8.1 \mathrm{mg})$, using as eluent $\mathrm{CHCl}_{3} / \mathrm{MeOH}(50: 1,800 \mathrm{~mL})$, and $13(8.1 \mathrm{mg})(2.5 \times 40 \mathrm{~cm}$, $\left.\mathrm{CHCl}_{3} / \mathrm{MeOH} 22: 1,600 \mathrm{~mL}\right)$ from $7 \mathrm{a}(830 \mathrm{mg})$, as well as compounds 8 (21.8 mg), 9 (12.9 mg), and $10(24.3 \mathrm{mg})(2.5 \times 40 \mathrm{~cm}$, $\mathrm{CHCl}_{3} /$ EtOAc $50: 1-14: 1,600 \mathrm{~mL}$ each) from $7 \mathrm{~b}$ (790 mg). Fraction $8(7.7 \mathrm{~g})$ was separated by vacuum liquid column $(5.5 \times 30 \mathrm{~cm}, 90 \mathrm{~g})$ using as eluent $\mathrm{CHCl}_{3} / \mathrm{MeOH}(35: 1-10: 1$, $1.5 \mathrm{~L}$ each) to afford subfractions $8 \mathrm{a}-8 \mathrm{~g}$. Subfractions $8 \mathrm{~d}$ $(55.3 \mathrm{mg})$ and $8 \mathrm{e}(880.3 \mathrm{mg})$ were gel-filtrated on Sephadex LH$20\left(2 \times 100 \mathrm{~cm}, \mathrm{CHCl}_{3} / \mathrm{MeOH} 1: 1,400 \mathrm{~mL}\right.$ and $\left.700 \mathrm{~mL}\right)$ to yield compounds 5 (13.0 $\mathrm{mg}$ ) and $\mathbf{1 4}(5.3 \mathrm{mg})$, respectively.

Isolate: Amauroamoienin (1): Yellow amorphous powder; $[\alpha]_{D}^{27}$ + 12.5 (c 3.2, MeOH); UV (MeOH) $\lambda_{\max }(\log \varepsilon) 365$ (1.35), 315 (1.56), 257 (3.02), 241 (2.77); IR (KBr) $v_{\max } \cdot \mathrm{cm}^{-1} 3353 \mathrm{~cm}^{-1}$, $2885,2270,1726,1621,1590,1490,1407,1296,1253,1195$, 1093, 884, 888, 670; ${ }^{1} \mathrm{H}$ and ${ }^{13} \mathrm{C}$ NMR data, see $\odot$ Table 1; positive ESIMS $m / z[\mathrm{M}+\mathrm{H}]^{+} 719$ (100); HREIMS $m / z[\mathrm{M}]^{+} 718.3871$ (calcd. for $\mathrm{C}_{46} \mathrm{H}_{54} \mathrm{O}_{7}, 718.3870$ ).

Bioassay of AChE inhibitory activity: Acetylcholinesterase inhibitory activity of all compounds was assayed by the spectrophoto- 


\begin{tabular}{|c|c|c|c|}
\hline Compound & Percentage of inhibition & Compound & Percentage of inhibition \\
\hline 1 & 14.6 & 7 & $<10$ \\
\hline 2 & $<10$ & 8 & $<10$ \\
\hline 3 & 46.3 & 9 & $<10$ \\
\hline 4 & $<10$ & 10 & $<10$ \\
\hline 5 & 25.5 & 11 & $<10$ \\
\hline 6 & $<10$ & Tacrine* & 53.0 \\
\hline
\end{tabular}

Table 2 AChE inhibitory activity of compounds 1-11 (\%) at $50 \mu \mathrm{M}$.

* Positive control $(0.333 \mu \mathrm{M})$

metric method developed by Ellman et al. [27] with slight modifications. S-Acetylthiocholine iodide, 5,5'-dithio-bis-(2-nitrobenzoic) acid (DTNB, Ellman's reagent), and acetylcholinesterase derived from human erythrocytes were purchased from Sigma Chemical. Compounds were dissolved in DMSO. The reaction mixture (totally $200 \mu \mathrm{L}$ ), containing phosphate buffer ( $\mathrm{pH} 8.0$ ), test compound $(50 \mu \mathrm{M})$, and acetylcholinesterase $(0.02 \mathrm{U} / \mathrm{mL})$, was incubated for $20 \mathrm{~min}\left(30^{\circ} \mathrm{C}\right)$. The reaction was initiated by the addition of $20 \mu \mathrm{L}$ of DTNB $(0.625 \mathrm{mM})$ and $20 \mu \mathrm{L}$ acetylthiocholine iodide $(0.625 \mathrm{mM})$ for the AChE inhibitory activity assay. The hydrolysis of acetylthiocholine was monitored at $405 \mathrm{~nm}$ after 30 min. Tacrine (Sigma-Aldrich 99\%) was used as a positive control with final concentration of $0.333 \mu \mathrm{M}$, and DMSO was used as negative control with final concentration of $0.1 \%$. All the reactions were performed in triplicate. The percentage of inhibition was calculated as follows: \% inhibition $=(E-S) / E \times 100(E$ is the activity of the enzyme without test compound and $S$ is the activity of enzyme with test compounds).

\section{Supporting information}

The original spectra of NMR and HREIMS data for the new compound (1) and general experimental procedures are available as Supporting Information.

\section{Acknowledgements \\ $\nabla$}

This work was financially supported by the Natural Science Foundation of Hainan (211020) and the National Nonprofit Institute Research Grant of CATAS (ITBB110301; 1630052012014). The authors are grateful to the members of the analytical group of the Institute of Tropical Bioscience and Biotechnology, Chinese Academy of Tropical Agricultural Sciences, for the spectral measurements.

\section{Conflict of Interest \\ $\nabla$}

We declare that we have no financial and personal relationships with other people or organizations that can inappropriately influence our work, and there is no professional or other personal interest of any nature or kind in any product, service, and/or company that could be construed as influencing the position presented in, or the review of the manuscript entitled.

\section{References}

1 Wu XL, Dai YC, Lin LH. Study on the Ganodermataceae of China I. Guizhou Sci 2004; 22: 27-34

2 Wu XL, Guo JR, Liao QZ, Xie SH, Xiao M. The resources and ecological distribution of Ganodermataceae in Hainan island. Mycosystema 1998; 17: $122-129$

3 Paterson RRM. Ganoderma - a therapeutic fungal biofactory. Phytochemistry 2006; 67: 1985-2001

4 Sliva D. Ganoderma lucidum in cancer research. Leuk Res 2006; 30 : 767-768

5 Stanley G, Harvey K, Slivova V, Jiang J, Sliva D. Ganoderma lucidum suppresses angiogenesis through the inhibition of secretion of VEGF and TGF- b1 from prostate cancer cells. Biochem Biophys Res Commun 2005; 330: 46-52

6 Aryantha INP, Adinda A, Kusmaningati S. Occurrence of triterpenoids and polysaccharides on Ganoderma tropicum with Ganoderma lucidum as reference. Aust Mycol 2002; 20: 123-129

7 Liu JQ Wang CF, Li Y, Luo HR, Qiu MH. Isolation and bioactivity evaluation of terpenoids from the medicinal fungus Ganoderma sinense. Planta Med 2012; 78: 368-376

8 Lee IS, Kim HJ, Youn UJ, Kim JP, Min BS, Jung HJ, Na MK, Hattori M, Bae $\mathrm{KH}$. Effect of lanostane triterpenes from the fruiting bodies of Ganoderma lucidum on adipocyte differentiation in 3 T3-L1 cells. Planta Med 2010; 76: 1558-1563

9 Oinonen P, Mettälä A, Vuorela P, Hatakka A. Screening of acetylcholinesterase inhibitors from fungal extracts. Planta Med 2006; 72: P-041 DOI: $10.1055 / \mathrm{s}-2006-949841$

10 Zhao JD, Xu LW, Zhang XQ. Taxonomic studies on the family Ganodermataceae of China II. Mycosystema 1983; 2: 159-167

11 Togashi H, Mizushina Y, Takemura M. 4-Hydroxy-17-methylincisterol, an inhibitor of DNA polymerase- $\alpha$ activity and the growth of human cancer cells in vitro. Biochem Pharmacol 1998; 56: 583-590

12 Ciminiello P, Fattoruss E, Magno S, Mangon A, Pansini M. Incisterols, a new class of highly degraded sterols from the marine sponge Dictyonella incisa. J Am Chem Soc 1990; 112: 3505-3509

13 Rukachaisirikul V, Ritthiwigrom T, Pinsa A, Sawangchote P, Taylor WC. Xanthones from the stem bark of Garcinia nigrolineata. Phytochemistry 2003; 24: 1149-1156

14 Westcrman PW, Gunasekera SP, Sultanbawa S, Uvais M, Kazlauskas R. Carbon-13 n.m.r. study of naturally occurring xanthones. Org Magn Reson 1977; 17: 631-636

15 Wan H, Sun RQ Wu DJ. Three sterols from Gyroporus castaneus. Nat Prod Res Dev 1999; 11: 18-20

16 Keller AC, Maillard MP, Hostettmann K. Antimicrobial steroids from the fungus Fomitopsis pinicola. Phytochemistry 1996; 41: 1041-1046

17 Ishikzuka T, Yaoita Y, Kikuchi M. Sterol constituents from the fruit bodies of Grifola frondosa (Fr.) S.F.Gray. Chem Pharm Bull 1997; 45: 17561760

18 Sun Y, Tian L, Huang J, Li W, Pei YH. Cytotoxic sterols from marine-derived fungus Pennicillium sp. Nat Prod Res 2006; 20: 381-384

19 Gao H, Hong K, Chen GD, Wang CX, Tang JS, Yu Y, Jiang MM, Li MM, Wang $N L$, Yao XS. New oxidized sterols from Aspergillus awamori and the endo-boat conformation adopted by the cyclohexene oxide system. Magn Reson Chem 2010; 48: 38-43

20 Kawagishi H, Katsumi R, Sazawa T, Mizuno T, Hagiwara T, Nakamura T. Cytotoxic steroids from the mushroom Agaricus blazei. Phytochemistry 1988; 27: 2777-2779

21 Yue JM, Chen SN, Lin ZW, Sun HD. Sterols from the fungus Lactarium volemus. Phytochemistry 2001; 56: 801-806

22 Lai GF, Zhu XD, Luo SD, Wang YF. Chemical constituents from Elsholtzia rugulosa. Chin Tradit Herb Drugs 2008; 39: 661-664 
23 Liu JJ, Liu XK. Chemical constituents from edible part of Pistacia chinensis. Chin Tradit Herb Drugs 2009; 40: 186-189

24 Liu ZY, Luo DQ. Chemical constituents from Trollius chinensis. Chin Tradit Herb Drugs 2010; 41: 370-373

25 Kwon HC, Kim KR, Zee SD, Cho SY, Lee KR. A new indolinepeptide from Peacilomyces sp.J300. Arch Pharm Res 2004; 27: 604-609

26 Ishizuka T, Yaoita Y, Kikuchi M. Sterol constituents from the fruit bodies of Grifola frondosa $\left(\mathrm{F}_{\mathrm{R}}\right.$.) S. F. $\mathrm{G}_{\mathrm{RAY}}$. Chem Pharm Bull 1997; 45: 17561760

27 Ellman GL, Courtney KD, Andres VJ, Featherstone RM. A new and rapid colorimetric determination of acetylcholinesterase activity. Biochem Pharmacol 1961; 7: 88-95

$\begin{array}{ll}\text { received } & \text { September 12, } 2012 \\ \text { revised } & \text { October 14, } 2012 \\ \text { accepted } & \text { October 21, } 2012\end{array}$

Bibliography

DOI http://dx.doi.org/10.1055/s-0032-1327951

Published online November 23, 2012

Planta Med 2013; 79: 87-91

(c) Georg Thieme Verlag KG Stuttgart · New York .

ISSN 0032-0943
Correspondence

\section{Prof. Dr. You Xing Zhao}

Institute of Tropical Bioscience and Biotechnology

Chinese Academy of Tropical Agricultural Sciences

Xueyuan road 4\#

Haikou 571101

China

Phone: + 8689866989095

Fax: +8689866989095

zhaoyouxing@itbb.org.cn

\section{Prof. Dr. Huai Rong Luo}

State Key Laboratory of Phytochemistry and Plant Resources in West China Kunming Institute of Botany

Chinese Academy of Sciences

Lanhei road 132\#

Kunming 650204

China

Phone: + 868715223225

Fax: + 868715223225

luohuairong@mail.kib.ac.cn 